\title{
EFEKTIVITAS SUSPENSI EKSTRAK ETANOL BATANG BROTOWALI (Tinospora crispa L.) TERHADAP PENINGKATAN BERAT BADAN TIKUS PUTIH JANTAN GALUR WISTAR (Rattus Norvegicus)
}

\author{
Anna Pradiningsih dan Astriani \\ Sekolah Tinggi Farmasi YPIB Cirebon \\ Email: annapradiningsih@gmail.com
}

\begin{abstract}
ABSTRAK
Batang Brotowali (Tinospora crispa L.) mengandung senyawa-senyawa aktif tinokrisposid, alkaloid dan apigenin (Flavon O-glicoside). Senyawa-senyawa aktif tersebut diduga sebagai penambah nafsu makan atau amara. Tujuan dari penelitian ini adalah untuk mengetahui efektivitas suspensi ekstrak batang brotowali (Tinospora crispa L.) sebagai amara terhadap peningkatan berat badan pada tikus putih. Jenis penelitian yang digunakan adalah penelitian eksperimental (experimental research) dengan metode pengambilan sampel purposive sampling. Pengujian dilakukan dengan membagi 15 ekor tikus menjadi 5 kelompok yaitu kelompok dengan perlakuan suspensi ekstrak batang brotowali 10\%, 40\%, 60\%, kontrol positif dan kontrol negatif. Hasil penelitian menunjukkan bahwa suspensi ekstrak batang brotowali mempunyai efek positif terhadap kenaikan berat badan pada tikus putih. Kenaikan tertinggi terjadi pada tikus dengan perlakuan ekstrak $40 \%$ dimulai pada hari ke 10 perlakuan, meningkat secara signifikan pada hari ke 15 dan mengalami penurunan kembali pada hari ke 20 . Dari hasil pengolahan uji statistik ANOVA diperoleh nilai signifikansi $0,551>0,05$ artinya $\mathrm{H} 0$ ditolak dan $\mathrm{H} 1$ diterima sehingga dapat disimpulkan bahwa suspensi ekstrak batang brotowali (Tinospora crispa L.) efektif terhadap kenaikan berat badan tikus putih.
\end{abstract}

Kata kunci: Brotowali, Tinospora crispa L, amara, tinokrisposid

\section{THE EFFECTIVITY OF BROTOWALI STEM EXTRACT (Tinospora crispa L.) TO INCREASE THE BODY WEIGHT OF WHITE RATS (Rattus Novergicus)}

\begin{abstract}
The stem of brotowali (Tinospora crispa L.) contains tinocrisposide, alkaloids and apigenin (Flavone O-glicoside). These active compounds were suspected to be an appetite enhancer compounds or amara. The purpose of this study was to determine the effect of brotowali stem extract (Tinospora crispa L.) to increase the body weight of male white rats (Rattus novergicus).This study was experimental research using purposive sampling method. The test was carried out on 15 rats whics was divided into 5 groups. Each group was treated with brotowali stem at concentration of $10 \%, 40 \%$, $60 \%$, positive control and negative control. The results showed that brotowali stem extract had a positive effect to increase the body weight of white rats. The highest increase occurred in mice treated with with $40 \%$ of brotowali, starting on the 10th day of the treatment, increased significantly on the 15th day and declined on the 20th day.
\end{abstract}


The ANOVA statistical test shows a significance value of $0.551>0.05$ means that $\mathrm{H} 0$ was rejected and $\mathrm{H} 1$ was accepted. Overall, it can be concluded that the suspension of brotowali stem extract was effective to increase the body weight of white mice.

Keywords: Tinospora crispa $L$, brotowali, tinocrisposide, amara

\section{PENDAHULUAN}

Tanaman Brotowali (Tinospora crispa L.) mengandung senyawa-senyawa aktif yang dapat meningkatkan aktifitas kerja enzim fosfatase dan alanine aminotransferase (Poongunran et. al., 2015). Peningkatan alanine aminotransferase akan mengakibatkan proses glukoneogenesis semakin tinggi. Peningkatan proses ini akan diiringi dengan peningkatan glikolisis sehingga kadar gula darah dalam darah akan berkurang dan terjadi peningkatan penggunaan energi. Kadar gula darah yang berkurang akan mempengaruhi hipotalamus di bagian otak sehingga memacu adanya peningkatan nafsu makan (Ariyanti, 2010; Kresnady, 2003).

Zat aktif yang terkandung dalam ekstrak batang brotowali memiliki rasa yang pahit sehingga perlu dibuat formulasi sediaan dengan bentuk suspensi, kapsul, serbuk atau tablet agar memudahkan dalam penggunaan dan memiliki nilai komersil yang baik. Penelitian Wahyuningsih dan Tasminatun (2007) menunjukkan bahwa ekstrak batang Brotowali dapat meningkatkan nafsu makan pada dosis 5,12 g/KgBB selama 10 hari pertama, setelah itu nafsu makan tidak meningkat lagi.

\section{METODE PENELITIAN Ekstraksi Bahan}

Ekstrak diperoleh dengan menyari serbuk simplisia batang brotowali dengan metode maserasi selama 7 hari. Waktu maserasi yang cukup lama dipilih karena semakin lama waktu ekstraksi maka akan semakin banyak senyawa yang tertarik. Pelarut yang digunakan adalah etanol $70 \%$, karena zat aktif pada batang brotowali yang diduga sebagai penambah nafsu makan adalah dari golongan alkaloid dan flavonoid yang memiliki sifat larut dalam pelarut polar. Filtrat hasil maserasi diuapkan dan dipekatkan untuk mendapatkan ekstrak kental. Ekstrak kental selanjutnya diencerkan secara berseri dengan larutan $\mathrm{Na}$ CMC $0,5 \%$ sehingga didapatkan ekstrak dengan konsentrasi $10 \%, 40 \%$ dan $60 \%$.

\section{Uji Kenaikan Berat Badan Tikus}

Kenaikan berat badan tikus diteliti menggunakan metode penelitian eksperimental (experimental research). Pengambilan sampel dilakukan dengan metode purposive sampling. Sampel dalam penelitian ini adalah batang tanaman Brotowali (Tinospora crispa L.) yang ditanam di Desa Kasokandel, Kabupaten Majalengka. Sebagai hewan uji digunakan tikus putih jantan galur wistar (Rattus norvegicus). Pengujian dilakukan dengan membagi 15 ekor tikus menjadi 5 kelompok, masing-masing kelompok berjumlah 3 ekor tikus yang ditempatkan pada kandang berbeda. Sebelum dilakukan pengujian, tikus diaklimatisasi selama dua minggu. Setelah itu masing-masing tikus ditimbang dan dicatat hasil penimbangan sebagai parameter berat badan awal tikus. Selanjutnya setiap kelompok uji diberi perlakuan berupa pemberian secara oral 2 $\mathrm{ml}$ ekstrak batang Brotowali dengan konsentrasi masing-masing10 \% $\left(\mathrm{X}_{1}\right)$, $40 \%\left(\mathrm{X}_{2}\right), 60 \%\left(\mathrm{X}_{3}\right)$, kontrol positif (Curcuma ${ }^{\circledR}$ plus) dan kontrol negative (suspensi CMC Na).

Pemberian ekstrak dilakukan setiap hari selama setiap hari selama 20 hari berturut-turut. Setiap 5 hari dilakukan 
penimbangan berat badan tikus untuk mengetahui penambahan berat badan tikus tersebut. Data yang dihasilka dianalisa secara statistik menggunakan Anova.

\section{HASIL DAN PEMBAHASAN}

Berdasarkan data hasil pengamatan seperti dapat dilihat pada Tabel 1., tikustikus dari seluruh kelompok uji dan kontrol positif mengalami dan kenaikan berat badansejak penghitungan pertama pada hari kelima perlakuan dengan kenaikan berat tertinggi rata-rata terjadi pada pengukuran hari ke 10. Kenaikan berat badan tidak terlihat pada kelompok kontrol negatif. Pada penimbangan hari ke 15 , berat badan tikus putih kelompok $X_{2}$ mengalami penurunan kembali sedangkan untuk kelompok tikus $X_{1}$ dan $X_{3}$ yang masih mengalami kenaikan berat badan badan yang signifikan. Berat badan tikus kelompok $\mathrm{X}_{1}$ dan $\mathrm{X}_{3}$ mengalami penurunan pada hari ke-20.

Tabel 1. Kenaikan Berat Badan Tikus Putih Selama Perlakuan dengan Ekstrak Batang Brotowali

\begin{tabular}{llllll}
\hline \multirow{2}{*}{ Variabel } & \multicolumn{5}{c}{ Berat Badan Tikus (gram) } \\
\cline { 2 - 6 } & BB Awal & Hari ke-5 & Hari ke-10 & Hari ke-15 & Hari ke-20 \\
\hline $\mathbf{X}_{\mathbf{1} .1}$ & 136 & 118 & 133 & 148 & 142 \\
$\mathbf{X}_{\mathbf{1} .2}$ & 124 & 129 & 149 & 157 & 149 \\
$\mathbf{X}_{\mathbf{1} \cdot \mathbf{3}}$ & 141 & 128 & 134 & 147 & 159 \\
Rata-rata & $\mathbf{1 3 3 , 6 7}$ & $\mathbf{1 2 5 , 0 0}$ & $\mathbf{1 3 8 , 6 7}$ & $\mathbf{1 5 0 , 6 7}$ & $\mathbf{1 5 0 , 0 0}$ \\
\hline $\mathbf{X}_{\mathbf{2} \cdot \mathbf{1}}$ & 129 & 144 & 152 & 135 & 159 \\
$\mathbf{X}_{\mathbf{2} .2}$ & 152 & 159 & 162 & 135 & 162 \\
$\mathbf{X}_{\mathbf{2} \cdot \mathbf{3}}$ & 151 & 130 & 131 & 143 & 134 \\
Rata-rata & $\mathbf{1 4 4 , 0 0}$ & $\mathbf{1 4 4 , 3 3}$ & $\mathbf{1 4 8 , 3 3}$ & $\mathbf{1 3 7 , 6 7}$ & $\mathbf{1 5 1 , 6 7}$ \\
\hline $\mathbf{X}_{\mathbf{3} \cdot \mathbf{1}}$ & 118 & 114 & 124 & 157 & 188 \\
$\mathbf{X}_{\mathbf{3} \cdot \mathbf{2}}$ & 148 & 129 & 149 & 165 & 133 \\
$\mathbf{X}_{\mathbf{3} \cdot \mathbf{3}}$ & 114 & 110 & 135 & 156 & 129 \\
Rata-rata & $\mathbf{1 2 6 , 6 7}$ & $\mathbf{1 1 7 , 6 7}$ & $\mathbf{1 3 6 , 0 0}$ & $\mathbf{1 5 9 , 3 3}$ & $\mathbf{1 5 0 , 0 0}$ \\
\hline K+.1 & 130 & 147 & 148 & 129 & 150 \\
K+.2 & 122 & 119 & 159 & 164 & 183 \\
K+.3 & 126 & 118 & 144 & 136 & 151 \\
Rata-rata & $\mathbf{1 2 6 , 0 0}$ & $\mathbf{1 2 8 , 0 0}$ & $\mathbf{1 5 0 , 3 3}$ & $\mathbf{1 4 3 , 0 0}$ & $\mathbf{1 6 1 , 3 3}$ \\
\hline K-.1 & 127 & 151 & 140 & 137 & 161 \\
K-.2 & 128 & 136 & 150 & 125 & 142 \\
K-.3 & 124 & 148 & 116 & 111 & 138 \\
Rata-rata & $\mathbf{1 2 6 , 3 3}$ & $\mathbf{1 4 5 , 0 0}$ & $\mathbf{1 3 5 , 3 3}$ & $\mathbf{1 2 4 , 3 3}$ & $\mathbf{1 4 7 , 0 0}$ \\
\hline
\end{tabular}

Keterangan:

$\mathrm{X}_{1}=$ Konsentrasi Suspensi Ekstrak Batang Brotowali 10\%

$\mathrm{X}_{2}=$ Konsentrasi Suspensi Ekstrak Batang Brotowali $40 \%$

$\mathrm{X}_{3}=$ Konsentrasi Suspensi Ekstrak Batang Brotowali 60\%

$\mathrm{K}^{+}=$Curcuma ${ }^{\circledR}$ plus

$\mathrm{K}-=$ Suspensi CMC Na

Persentase peningkatan berat badan setiap kelompok tikus dapat dilihat mulai dari kelompok $\mathrm{X}_{1}$ dengan berat badan awal tikus 133,67 g kemudian mulai terjadi peningkatan pada hari ke-10 menjadi 138,67 g (meningkat $3.75 \%$ ). 
Pada hari ke-15, berat badan kelompok $X_{1}$ menjadi $150,67 \mathrm{~g}$ (meningkat $8,66 \%$ ) dan pada hari ke-20 mengalami penurunan kembali menjadi 150,00 g. Pada $X_{2}$, berat badan awal tikus yaitu 144,00 g kemudian mengalami peningkatan pada hari ke-10 yaitu menjadi 148,33 g (meningkat 5.8\%). Peningkatan berat badan yang signifikan pada tikus kelompok $\mathrm{X}_{2}$ terjadi pada hari ke-20 yaitu menjadi 151,67 g (6.2\%). Pada tikus kelompok $\mathrm{X}_{3}$, berat badan awal tikus yaitu $126,67 \mathrm{~g}$ terjadi peningkatan pada hari ke-10 menjadi $136,00 \mathrm{~g}(7,4 \%)$ dan mengalami peningkatan yang signifikan pada hari ke-15 menjadi 159,33 g (17\%). sedangkn pada hari ke-20 mengalami penurunan kembali menjadi 150,00 g. Pada perlakuan dengan kontrol positif, berat badan awal tikus adalah $126,00 \mathrm{~g}$ dan mengalami peningkatan pada hari ke-10 menjadi 143,00 g $(13.5 \%)$, kemudian terjadi peningkatan pada hari ke-20 menjadi 161,33g (12.9\%). Pada data kontrol negatif berat badan awal tikus yaitu 126,33 g dan mengalami peningkatan dan penurunan yang tidak beraturan yaitu pada hari ke-5 mengalami peningkatan menjadi 145,00 g (15\%) dan menglami penurunan yang signifikan pada hari ke 15 yaitu menjadi 124,33 g, kemudian pada hari ke-20 mengalami peningkatan kembali menjadi 147,00 g.Peningkatan berat badan tikus selama perlakuan terjadi karena adanya efek positif batang brotowali dalam meningkatkan nafsu makan (Tasminatun dan Wahyuningsih, 2007).

Hasil skrining Ekstrak Daun Brotowali dengan menggunakan pereaksi Mayer positif mengahasilkan endapan putih dan menggunakan KLT menunjukan bahwa ekstrak metanol daun brotowali mengandung alkaloid dengan menggunakan fase diam silika gel GF 254 dan menggunakan eluen Metanol : Etil asetat dengan (4:1) terjadi pemisahan yang baik dan menghasilkan bercak noda orange kuat dibawah sinar UV dengan penyemprotan reagen pereaksi dragendrof dengan nilai Rf 0,56 (Usman, R, 2016). Senaywa Alkaloid ini yang dapat digunakan sebagai penambah nafsu makan (Sutardi, 2016)

Efek ini ekstrak batang brotowali terhadap peningkatan nafsu makan setara dengan efek yang diberikan oleh ekstrak kurkumin dari kunyit seperti terlihat dari kenaikan berat badan pada kelompok tikus kontrol positif yang diberi perlakuan dengan suplemen yang mengandung senyawa kurkumin. Grafik kenaikan berat badan tikus selama perlakuan dengan ekstrak batang brotowali dapat dilihat pada Gambar 1.

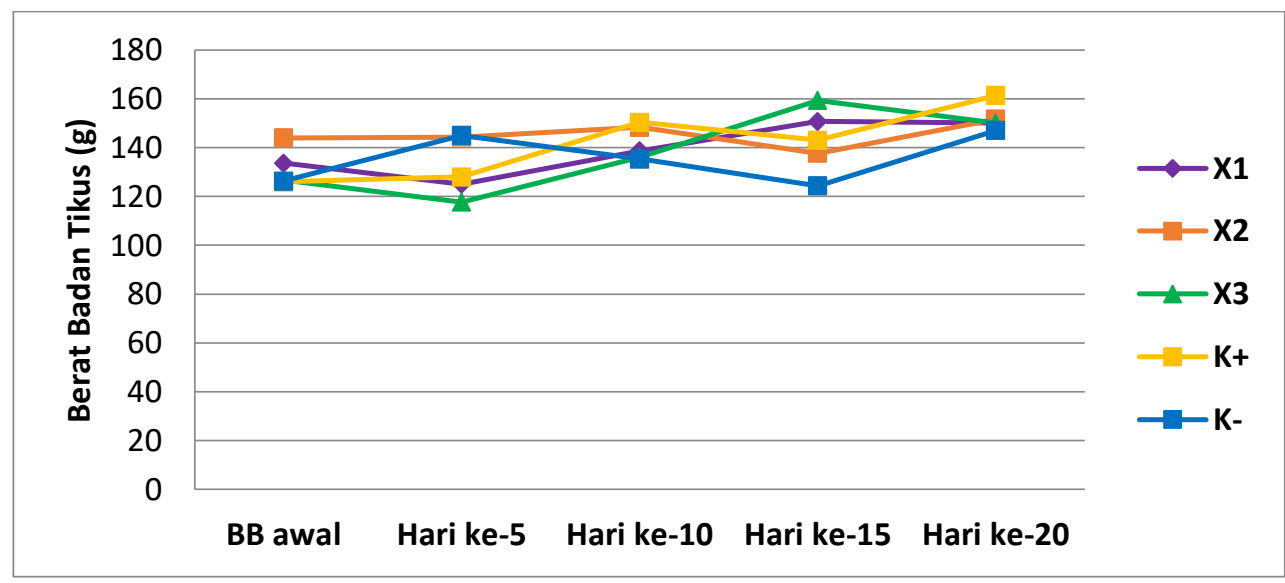

Gambar 1. Grafik Peningkatan Berat Badan Tikus Selama Perlakuan Dengan Ekstrak Batang Brotowali 
Berdasarkan grafik peningkatan berat badan tikus, terlihat bahwa pemberian ekstrak batang brotowali secara terus menerus kurang efektif untuk meningkatkan berat badan dalam jangka panjang, namun diperlukan penelitian lebih lanjut untuk mendapatkan data yang lebih menyeliruh. Dari hasil pengolahan data uji ANOVA diperoleh nilai signifikansi 0,551>0,05 artinya $\mathrm{H} 0$ ditolak dan $\mathrm{H} 1$ diterima sehingga dapat disimpulkan bahwa suspensi ekstrak batang brotowali mempunyai efek positif terhadap meningkatnya berat badan tikus putih pada jangka waktu tertentu.

\section{KESIMPULAN}

Pemberian suspensi ekstrak batang Brotowali (Tinospora crispa L.) dengan konsentrasi $10 \%$, $40 \%$ dan $60 \%$ memiliki efektivitas sebagai amara terhadap peningkatan berat badan tikus putih. Dosis paling efektif adalah ekstrak dengan konsentrasi 40 persen dengan jangka waktu perlakuan 10 hari.

\section{DAFTAR PUSTAKA}

Ariyanti R. 2010. Aktivitas alkalin fosfatase serum dan gambaran histopatologi ginjal tikus yang diberi kelapa kopyor pascainduksi parasetamol. Skripsi Sarjana. Program Studi Biokimia, Fakultas MIPA, IPB. Bogor.

Kresnady, B. 2003. Khasiat dan Manfaat Brotowali si Pahit yang Menyembuhkan. PT. Agromedia Pustaka. Jakarta.

Poongunran J, H.K.I Perera, W.I.T Fernando, L. Jayasinghe, dan R. Sivakanesan R. $\alpha-$ glucosidase and $\alpha$-amylase inhibitory activities of nine Sri Lankan antidiabetic plants. Journal of Pharmaceutical Research. 7(5): 365-374.

Sutardi, 2016, Kandungan Bahan Aktif Tanaman Pegagn dan Khasiatnya untunk Meningkatkan Sistem Imun Tubuh,
Jurnal Litbang Pertanian Vol. 35 No. 3 September 2016: 121-130.

Usman, R, dkk, 2016, Skrining Fitokimia Senyawa Alkaloid Ekstrak Daun Brotowali (Tinospora Crispa.L) Asal Gorontalo dengan Metode Kromatografi Lapis Tipis, UNG Respiratory.

Wahyuningsih, N. dan S. Tasminatun S. 2007. Efek infusa batang brotowali (Tinospora crispa) terhadap nafsu makan dan berat badan tikus putih (Rattus norvegicus). Mutiara Medika. 7(2): 105-110. 